\title{
EDUKASI ONLINE TERHADAP PERUBAHAN PERILAKU MENJAGA KEBERSIHAN GIGI PADA MULUT SELAMA MASA PANDEMI
}

\author{
Ajeng Yumna Azizah ${ }^{1}$, Suci Erawati ${ }^{2}$, Idamawati Nababan ${ }^{3}$ \\ Fakultas Kedokteran Gigi Universitas Prima Indonesia ${ }^{l}$ \\ e-mail : 'ajeng.yumna3@gmail.com, ${ }^{2}$ esuci64@gmail.com, ${ }^{3}$ idamawatinababan@outlook.com
}

\begin{abstract}
Oral cavity is one of the crucial parts of our body. Oral cavity represents our oral health because there are a lot of disease symptoms from our oral cavity. Systemic disease could cause poor oral and dental health. Online education is one way to improve someone's oral and dental hygiene level. Online education is one of learning process with the internet as a media, so the users can connect with everybody, whenever and wherever they want. Purpose of this research is to determine the effect of online education towards students' oral and dental hygiene behavior change in YPSA Senior High School Medan during COVID-19 pandemic. This research was conducted with an observational analytic method with cross sectional design with a total sample of 55 students. Sample was determined by accidental sampling technique. Data was analyzed using a statistics dependent $t$ test. Results showed that there were any behavior changes before and after online education. Conclusion of this research showed there were any significant effect of online education towards students' oral and dental hygiene behavior change in YPSA Senior High School Medan during COVID-19 pandemic.
\end{abstract}

Keywords : Online education, oral hygiene

\begin{abstract}
ABSTRAK
Mulut merupakan bagian krusial bagi tubuh, selain ini dikatakan juga bahwa mulut merupakan cermin dari Kesehatan tubuh, karena dari mulut dapat dilihat gejala beberapa penyakit umum yang lainnya. Gangguan sistemik dapat disebabkan oleh kondisi gigi serta mulut yang kebersihannya buruk. Edukasi online dapat menjadi salah satu cara yang dapat dilakukan untuk meningkatkan tingkat kebersihan gigi serta mulut pada seseorang. Edukasi online adalah suatu proses belajar mengajar yang memakai jaringan internet yang dapat memudahkan penggunanya terhubung tanpa keterbatasan waktu dan tempat dengan siapa saja. Tujuan penelitian ini adalah untuk mengetahui pengaruh edukasi online terhadap perubahan perilaku menjaga kebersihan gigi pada mulut selama masa pandemi di SMA YPSA Medan. Jenis penelitian ini merupakan penelitian obeservasional analitikmenggunakan desain cross sectional. Jumlah sampel 55 orang. Penentuan sampel memakai Teknik Accidental sampling. Uji analisis yang dipakai yaitu dependent $t$ test. Hasil penelitian menunjukkan terdapat perubahan perilaku menjaga kebersihan gigi pada mulut sebelum dan sesudah edukasi online. Kesimpulan penelitian ini yaitu ada pengaruh edukasi online terhadap perubahan perilaku menjaga kebersihan gigi pada selama masa pandemi pada di SMA YPSA Medan.
\end{abstract}

Kata Kunci : Edukasi online, kebersihan gigi dan mulut

\section{INTRODUCTION}

\section{Background}

Health is a condition when every single person has good physical, spiritual and mental conditions that could affect other people to live productively. Health affects every part of our life comprehensively, for example oral health. Oral health can affect the whole body, because every food and beverages that we consume orally were processed thoroughly by our digestive system, turning them into energy that could maintain and repair our body tissues (1)
If there aren't any diseases that occur from hard and soft tissue or other supportive oral cavity tissue, it means that oral and dental health are in good condition. Healthy oral and dental make the person able to eat normally, interact and talk normally without any dysfunction, aesthetic disorder, abnormal occlusion, tooth loss, and discomfort because of disease, so the person could live socially and economically productive (Indonesia Health Ministry, 2015). Oral cavity is one of important part of our body and reflects our dental health because there are lots of common disease symptoms that could be detected from our oral cavity. Poor oral and dental hygiene could evoke infection and cause systemic disease ${ }^{(2)}$ 
Vol. 16 No. 1 Januari - April 2021

Some of Indonesia citizens have a poor awareness regarding oral and dental hygiene that make them visit the dentist only because of oral discomfort or symptoms. Indonesia citizens come to the dentist when their dental problems are complicated, so the cost of dental treatment is higher than regular dental treatment. This condition shows that Indonesia's citizen capability and motivation to get dental treatments are pretty low, there are only $7 \%$ of the total population ${ }^{(3)}$

Health worker behavior, environment, and service are several factors that could affect citizen oral and dental hygiene. Behavior is one of the most important factors that could affect oral and dental hygiene. (Narulita et al., 2016). It is important for every person to maintain their oral and dental hygiene. This action could prevent oral and dental disease, like dental caries and other oral diseases. Around one fifth of the population in the world are teenagers. WHO stated that teenagers within 10 until 19 years old as 'a suitable period' to learn and build habits regarding their oral and dental hygiene ${ }^{(4)}$

During teenagers' growth and development period, they often have health problems, including oral and dental hygiene. WHO suggests teenager students as an appropriate age group to learn good behavior by introducing and promoting body health, educating dental hygiene, and maintaining healthy oral cavity. Gingival inflammation, halitosis, caries, and hard and soft tissue damage caused by trauma are some of oral cavity problems that occurs within teenager ${ }^{(5)}$

Caries is one of the diseases that mostly occur within teenagers. Lack of awareness to maintain oral and dental health cause this health problem (Indonesia Health Department, 2016). A solution to prevent this problem by maintaining oral and dental hygiene. Because of poor oral and dental education, a lot of people think that this problem doesn't matter for them ${ }^{(6)}$

As the time goes by, technology development improves massively during this decade. The Internet is one of familiar things in Indonesia, with 72,7 internet users, of which $20 \%$ of them are teenagers. Through social media they can communicate with everybody. Social media is one of the media that involves the internet as the media, so they could communicate without time and place limitation ${ }^{(7)}$

In early 2020, the world was shocked by the new type of worldwide transmitted virus, Coronavirus (SARS-CoV-2). This virus can cause a disease called Coronavirus disease 2019 (COVID-19). This virus was discovered for the first time in Wuhan, China by the end of December 2019. There are 65 countries that have already been exposed to the COVID-19 virus (WHO Data, March $1^{\text {st }}$ 2020). According to
WHO, Coronavirus could cause some major health problems in humans and animals. Mild respiratory tract disturbance like cough and flu to severe symptoms like Middle East Respiratory Syndrome (MERS) and Severe Acute Respiratory Syndrome (SARS) are several symptoms of new type coronavirus disease ${ }^{(8)}$

During COVID-19 pandemic, to prevent any kinds of coronavirus distribution to ourselves and our family, government encourage citizens implementing healthy and clean life behavior, following by other positive activity. Using hand soap with flowing water and hand sanitizer, balanced diet and nutrition, staying inside when there isn't an urgent situation are recommended by the Health Ministry (Indonesia Health Ministry, 2020). Indonesia Basic Health Research in 2018 showed that the majority of dental problems in Indonesia is dental caries/pain around $45,3 \%$, and majority of oral problems is gingival inflammation or abscess around $14 \%$ (Data Information Center of Indonesia Health Ministry, 2019). This data showed that oral disease that happen to citizens should be solve in this pandemic situation to prevent the increase of dental pain and preventive case $^{(8)}$

A lot of citizens don't realize during COVID-19 pandemic, except if there are any oral and dental emergency problem, they are advised to postpone dental treatment or make a visit to dentist because dentist profession is susceptible with COVID-19 exposure and has a higher risk, aside from medical workers who work directly with COVID-19 patients (Indonesia Health Ministry, 2020). COVID19 could be spread through droplets (saliva spurts). Dentists tend to really close with a patient's droplet while they're giving any kind of dental treatment. This interaction could cause faster exposure between patients and dentists because anybody could be suspected with COVID-19 as a COVID-19 silent killer. COVID-19 silent killer could be any person or everybody who had contact with COVID-19, but they don't show any COVID-19 symptoms and could spread the virus through other people or any objects ${ }^{(8)}$

Citizens are recommended practicing social distancing to reduce the transmission of COVID-19 virus. To avoid any dental pain or problems, citizens have to be involved with dental and oral hygiene rehabilitation, so it could suppress dental treatment costs, and also reduce any risk of COVID-19 exposure in dental practice.

Based on this explanation, researchers need to conduct this research "Online Education towards Students' Oral and Dental Hygiene Behavior Change in YPSA Senior High School Medan during Covid-19 Pandemic".

\section{OBJECTIVES}




\section{General Objectives}

To determine online education method effects towards students' oral and dental hygiene behavior change in YPSA Senior High School Medan during COVID-19 pandemic.

\section{Specific Objectives}

1. To determine oral and dental hygiene behavior score during pandemic before online education.

2. To determine oral and dental hygiene behavior score during pandemic after online education.

3. To determine oral and dental hygiene behavior score difference before and after online education during pandemic.

\section{METHOD}

This research was conducted with an observational analytic method with cross sectional design. This research started from January until February 2021. This research was conducted in YPSA Senior High School Medan, Setia Budi Streets number 19, Medan, North Sumatera. Populations of this research were YPSA Senior High School Medan students' age between 14-16 years old with a total 122 students, which 55 students were the samples. Sample was determined by accidental sampling technique. The independent variable was online education, and dependent variables were YPSA Senior High School Medan students' oral and dental hygiene behavior during pandemic. Data was taken according to the pretest and posttest quiz. The data was analyzed with two step analysis, first analysis was univariate analysis and then bivariate analysis using statistic dependent $t$ test.

\section{RESULT}

\section{Respondent characteristic}

Respondent characteristics based from Table 1 showed that the majority of respondents were 15 years old with a total of 44 students $(80 \%), 16$ years old with a total of 6 students $(10,9 \%)$, and 14 years old with a total of 5 students $(9,1 \%)$. Based on their gender, respondents were dominated by females with a total of 33 students, and male students with a total $\begin{array}{llll}\text { of } & 22 & \text { students }\end{array}$

Table 1. Respondent characteristic $(\mathrm{n}=55)$

\begin{tabular}{lccc}
\hline & Characteristic & $\mathbf{N}$ & \% \\
\hline Age & & 5 & 9,1 \\
& 14 & 44 & 80,0 \\
& 15 & 6 & 10,9 \\
\hline 16 & 55 & 100,0 \\
\hline \multirow{2}{*}{ Gender } & Total & & \\
& Male & 22 & 40,0 \\
& Female & 33 & 60,0 \\
\hline & Total & 55 & 100,0 \\
\hline
\end{tabular}

\section{Average Score of Oral and Dental Hygiene Behavior Change during COVID-19 Pandemic Before and After Online Education}

Table 2. Average score of oral and dental hygiene behavior change during COVID-19 pandemic before and after online education

\begin{tabular}{ccc}
\hline Treatment & $\overline{\boldsymbol{x}}$ & SD \\
\hline Before & 53,36 & 3,85 \\
After & 54,11 & 3,86
\end{tabular}

Online Education Effect on Oral and Dental Hygiene Behavior Change during COVID-19 Pandemic

Table 3 showed that average score of oral and dental hygiene behavior during COVID-19 Pandemic
Table 2 showed that the average score of Oral and Dental Hygiene Behavior during COVID-19 Pandemic before online education was 53,36 $\pm 3,85$ and after online education was $54,11 \pm 3,86$

before education was $53,36 \pm 3,85$ and after online education was $54,11 \pm 3,86$ with difference score between before and after education was $0,75 \pm 0,01$. Analysis statistic paired $\mathrm{t}$ test showed that $\mathrm{p}$ value $=$ $0,045(\mathrm{p}<0,05)$. There were significant effect between oral and dental hygiene behavior during COVID-19 pandemic before and after online education. From this 
Vol. 16 No. 1 Januari - April 2021

result, it stated that there were significant online education effects on oral and dental hygiene behavior

change during COVID-19 pandemic

Table 3 Online education effect to oral and dental hygiene behavior change during COVID-19 pandemic

\begin{tabular}{ccccc}
\hline Treatment & $\overline{\boldsymbol{x}} \pm$ SD & Mean diff & p value & Description \\
\hline Before & $53,36 \pm 3,85$ & & & There were any \\
After & $54,11 \pm 3,86$ & $0,75 \pm 0,01$ & 0,045 & $\begin{array}{c}\text { significant } \\
\text { difference }\end{array}$ \\
\hline
\end{tabular}

\section{DISCUSSION}

COVID-19 is one of the newest respiratory diseases caused by SARS-CoV-2 virus. The World Health Organization (WHO) stated the coronavirus outbreak as a global pandemic. Indonesia is one of the countries which is impacted by this situation. Coronavirus transmitted through droplets that come out when people cough or sneeze. This virus was found in oral cavity and oropharyngeal. Nevertheless, oral and dental rehabilitation is important in order to maintain body health entirely ${ }^{(9)}$

Oral hygiene can affect our body health, because foods and beverages that we consume producing energy that we need to rehabilitate and repair our body tissue (Svalastog AL et al., 2017). Having healthy oral and dental allows people to eat, speak and interact with other people without any dysfunction, aesthetic problems, occlusion abnormalities, teeth loss or any other discomfort because of any oral disease, so people could live in economic and social stability ${ }^{(10)}$

Based on the research result, there are significant effects of online education with oral and dental health behavior change during COVID-19 pandemic. Result of this research compatible with research by Ekoningtyas et al (2020) that respondent behavior changes associated with dental health behavior, like brushing teeth two times per day after breakfast and before went to bed for four weeks with online education. This research also compatible with research by Mulyani et al (2020) stated that online education that had been done routinely with a certain period of time could improve dental knowledge during pandemic.

Accessibility, flexibility and connectivity of the internet are implemented by online education. Internet provides online education method, so there are many kinds of learning ways that students can access. Research by Zhang et al., (2004) showed that internet and multimedia usage can distribute knowledge, remodel any lessons and use as alternative learning method which is same with conservative method ${ }^{(11)}$

Learning system with online education could connect teachers with their students via online using the internet (Kuntarto, 2017). Online education enables interaction between teachers and students through the web even though they were far apart ${ }^{(12)}$

According to this research, it had been proved that online education could increase student's behavior to maintain their oral and dental hygiene during COVID-19 pandemic. It showed that students' behavior changed after online education.

\section{CONCLUSION}

1. Average score of oral and dental hygiene behavior change in YPSA Senior High School Medan during COVID-19 pandemic before online education was $53,36 \pm 3,85$.

2. Average score of oral and dental hygiene behavior change in YPSA Senior High School Medan during COVID-19 pandemic after online education was $54,11 \pm 3,86$.

3 . The result of statistics analysis paired t test showed that there were any significant effect of online education towards oral and dental hygiene behavior change in YPSA Senior High School Medan during COVID-19 pandemic with $\mathrm{p}$ value $=0.045(\mathrm{p}<0,05)$

\section{SUGGESTION}

1.We suggest that students need to improve oral and dental hygiene to prevent various kinds of oral and dental disease.

2. We suggest that parents can monitor and educate their child/children to maintain oral and dental hygiene so they can prevent various kinds of oral and dental disease.

3. We suggest that medical workers and teachers should use online education as an alternative method, especially to maintain their oral and dental hygiene during COVID-19 pandemic. 


\section{REFERENCE}

1. Svalastog AL, Donev D, Kristoffersen NJ, Gajovic S. 2017. Concepts and defenitions of health and healthrelated values in the knowledge landscapes pf the digital society. Croat Med J.; Vol 58: 431-5

2. Ircham, Machfoedz, 2015. Menjaga Kesehatan gigi dan mulut anak-anak, ibu hamil. Yogyakarta. Fitra Maya

3. Agusta, M.V.R., Ade, I.A.K., Muhammad, D.F. 2014. Hubungan pengetahuan Kesehatan gigi dengan kondisi Oral Hygiene anak tunarungu usia sekolah. Semarang : Medali Jurnal 2 (1): 53-54.

4. Rattu A.J.M, Wicaksono D, Wowor V.E. 2013. Hubungan antara status kebersihan mulut dengan karies siswa Sekolah Menengah Atas Negeri 1 Manado. Manado, P.1-10

5. Lesar AM, Pangemanan DHC, Zuliari K. 2015. Gambaran status kebersihan gigi dan mulut serta status gingiva pada anak remaja di SMP Advent Watulaney Kabupaten Minahasa. Jurnal eG. 3(2): 303,306.

6. Damafitra, Lita. 2015. Efektifitas video dan Bahasa isyarat sebagai media penyuluhan Kesehatan gigi dan mulut pada anak penderita tunarungu.

7. Felita, P., dkk. 2016. Pemakaian media social dan self concept pada remaja. Jurnal Ilmiah Psikologi Manasa, 5 (1), $32 \& 33$.

8. Kemenkes RI. (2020). Pedoman pencegahan dan pengendalian Coronavirus Disease (COVID-19). Kemenkes RI Dirjen Pencegahan dan Pengendalian Penyakit (P2P). Jakarta

9. Koesoemawati, R. 2020. Peran ibu dan remaja dalam pemeliharaan Kesehatan gigi di masa pandemic covid-19. Prosiding Webinar Nasional Peranan Perempuan/Ibu dalam Pemberdayaan Remaja di Masa Pandemi COVID-19, Universitas Mahasaraswati Denpasar.

10. Kementrian Kesehatan Ri. Profil Kesehatan Indonesia 2015. Jakarta: Kementrian Kesehatan Ri, 2016

11. Sadikin, A; and A. Hamidah. 2020. Online learning in the middle of the covid-19 pandemic. BIODIK: Jurnal Ilmuah Pendidikan Biologi 6(2): 214-24

12. Bell, S; C. Douce; S. Caeiro; A.Teixeira; R. Martin-Aranda; and D. Otto. 2017. Sustainability and distance learning: a diverse European experience? Open Learning 32 (2): 95-102. 